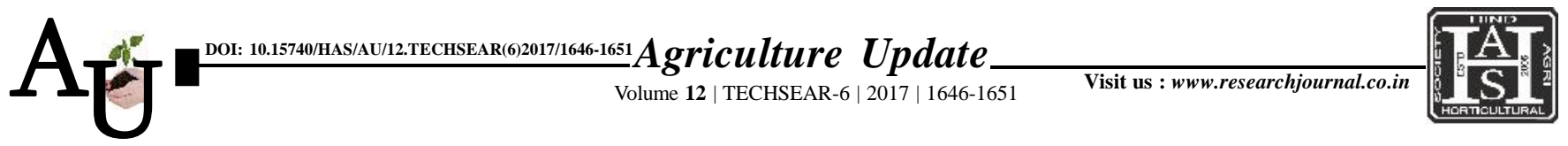

\title{
Rевеавсн Автыст: A serological report on groundnut bud necrosis virus (GBNV) and tobacco streak virus (TSV) infecting groundnut and parthenium in Guntur and Prakasam districts of A.P.
}

\author{
G. SOWMYA LAKSHMI AND V. MANOJ KUMAR
}

Article Chronicle:

Received :

17.07.2017;

Accepted :

01.08.2017

KEY WoRds:

GBND, PSND, TSV,

GBNV, DAC-ELISA

SUMMARY : Samples showing symptoms ranging from chlorosis to necrosis, collected from different fields during the survey in Guntur and Prakasam districts during Rabi 2013-14 alone cannot determine the presence of disease and its casual organism. To consolidate, these samples were subjected to a serological test DAC-ELISA. Out of 38 groundnut and parthenium samples of Guntur district tested, 22 samples were positive for GBNV while two were positive to TSV. Out of 24 samples of Prakasam district, 13 were positive to GBNV, two were positive to TSV alone and nine samples were positive to both viruses (mixed infections).

How to cite this article : Lakshmi, G. Sowmya and Kumar, V. Manoj (2017). A serological report on groundnut bud necrosis virus (GBNV) and tobacco streak virus (TSV) infecting groundnut and parthenium in Guntur and Prakasam districts of A.P. Agric. Update, 12(TECHSEAR-6) : 1646-1651; DOI: 10.15740/HAS/AU/12. TECHSEAR(6)2017/1646-1651.

Author for correspondence :

\section{G. SOWMYA}

LAKSHMI

Department of Plant Pathology, Agricultural College, BAPATLA (A.P.) INDIA

Email: sowmya.gorle@ gmail.com 